\title{
Innovation and service-dominant logic
}

\author{
Kun-Huang Huarng ${ }^{1}$ - Amparo Cervera ${ }^{2}$ - Francisco Mas-Verdu ${ }^{3}$
}

\begin{abstract}
Radical changes have occurred in innovation management. Traditional goods-dominant logic has shifted to service-dominant logic, where value is created for use instead of exchange. Customers are tied to organizations to co-create value. The focus of this special issue is on high quality, original, unpublished research, case studies, and implementation experiences. The issues are covered, including the collaborative workplaces for innovation in service companies, the financial crisis in hospitality industry, the role of quality management in innovation, and the value logic in service.
\end{abstract}

Keywords Collaborative workplaces · Financial crisis · Hospitality · Quality management $\cdot$ Value logic

\footnotetext{
The guest editors of this special issue thank all paper submitters, including those who attended 2017 Global Innovation and Knowledge Academy (GIKA) Conference. Special thanks go to S.M. Lee, Editor of Service Business, for offering a special issue on Innovation and Service-Dominant Logic. We thank all reviewers for providing constructive comments and suggestions to help the authors improve their papers.

Kun-Huang Huarng

khhuarng@mail.fcu.edu.tw

1 Department of International Trade, Feng Chia University, 100 Wenhwa Road, Seatwen, Taichung 40724, Taiwan

2 University of Valencia, València, Spain

3 Universitat Politècnica de València, València, Spain
} 


\section{Introduction}

The way organizations manage innovations has undergone radical changes over the years. First, innovations are not developed solely within the boundaries of organizations. As well as arising from internal sources, innovations occur in collaboration with an extensive network of external agents, including suppliers, partners, and customers (Chesbrough 2003; Nambisan and Sawhney 2007). Second, the core elements of innovations are not only tangible, but also intangible, taking the form of information that is transferred to customers. The emphasis has thus shifted from the physical attributes of goods to the values or experiences that are perceived by customers (Prahalad and Ramaswamy 2004; Vargo and Lusch 2004, 2008; Lee 2015). Third, innovations can shape the strategy of organizations (Lee and Olson 2010). Innovations are now considered part of the broader context of suppliercustomer relationships (Cantista and Tylecote 2008). Organizations aim to develop a continuous flow of innovative solutions to specific customer problems. The notion of innovations no longer refers to something new in absolute terms but rather something that is new for a particular customer.

Much innovation research has followed the principles of goods-dominant logic (Vargo and Lusch 2004, 2008). Goods-dominant logic focuses on optimizing and managing tangible results in economic processes. In goods-dominant logic, value is created by organizations and is usually distributed through the exchange of goods and money. In this exchange, the roles of producers and consumers are distinct, and value creation is often conceived as a series of activities that are performed by organizations (Vargo et al. 2008). Rather than stressing the production and supply of tangible goods, service-dominant logic is linked to value-in-use (Vargo and Lusch 2008). In service-dominant logic, the roles of producers and consumers are indistinct: Value is usually co-created in interactions among producers and consumers through the integration of resources (Vargo et al. 2008).

Scholars have enriched the theory on service-dominant logic by adapting it to specific contexts. But the key element that explains the transition from goodsdominant to service-dominant logic can be expressed as follows: "the business process is informed between understanding the purpose as selling things to people and understanding it to be serving the exchange partner's need" (Lusch and Vargo 2014). This new conceptualization of service innovation in service-dominant logic highlights the key role of actors in social systems. These actors create changes in structures expressed in innovative ways that allow actors to co-create value (Edvardsson and Tronvoll 2013; Koskela-Huotari et al. 2016). This special issue, titled "Innovation and Service-Dominant Logic," focuses on the need for a broader conceptualization of services and innovations to explain how both are generated, disseminated, and applied. The special issue also probes into service-dominant logic's potential as a framework to explain innovation processes (Vargo and Lusch 2004, 2006, 2008). As Michel et al. (2008) report, service-dominant logic offers a novel theoretical perspective that demands a reassessment of the nature and management of innovation and a better understanding of the innovation and value creation processes. Service-dominant logic offers a suitable framework for 
understanding innovation in services by fusing services and goods into an integrated ecosystem where customers play a key role. Consequently, service-dominant knowledge is increasingly being recognized as a viable approach in service innovation research (Ordanini and Parasuraman 2011; Mas-Tur and Soriano 2014; Lusch and Nambisan 2015).

This special issue focuses on high quality, original, unpublished research, case studies, and implementation experiences. The articles are introduced below.

\section{Contributions}

The first contribution, "Collaborative workplaces for innovation in service companies: Barriers and enablers for supporting new ways of working," is by Manca, Grijalvo, Palacios, and Kaulio. This article provides a guide for companies that seek to design new ways of working based on employee collaboration and flexibility. The study is based on interviews with employees who hold different positions in multinational companies and Spanish subsidiaries. The study consists of three parts: identification of the factors that encourage or hinder the performance of collaborative jobs; exposure to the mechanisms that reinforce barriers and generate tensions between different areas; and investigation of how companies can use enablers to reduce such tensions. In "Quality Management as a driver of Innovation in the Service Industry," Roig-Tierno, González-Cruz, and Botella Carrubi study how quality management is linked to exploratory innovation, thereby influencing the development of new products and services in underserved markets. The strength of an organization is its capacity for innovation. This capacity is explained by customer orientation, competitive strategy, and the motivation of the manager to adopt quality management.

In "Predicting hospitality financial distress with ensemble models: the case of US hotel, restaurant, and amusement recreation," Kim investigates the dominant factors of the financial difficulties of US hotel companies between 1988 and 2010. To do so, the author uses joint models that combine the characteristics and advantages of specific models. The study is based on data from restaurants, hotels, and places of entertainment. The author concludes that the future direction of research should be to predict possible bankruptcies.

Finally, the objective of the study titled "Value logics for service innovationPractice driven implications for service-dominant logic," by Parida, Oghazi, and Churimalla, is to understand the creation of value in service innovations by productfocused manufacturing companies. The authors develop a theoretical model based on product-, service-, virtual-, and systemic-based value logics.

\section{References}

Cantista I, Tylecote A (2008) Industrial innovation, corporate governance and supplier-customer relationships. J Manuf Technol Manag 19(5):576-590 
Chesbrough $\mathrm{H}$ (2003) Open innovation: the new imperative for creating and profiting from technology. Harvard Business School Press, Boston

Edvardsson B, Tronvoll B (2013) A new conceptualization of service innovation grounded in SD logic and service systems. Int J Qual Serv Sci 5(1):19-31

Koskela-Huotari K, Edvardsson B, Jonas JM, Sörhammar D, Witell L (2016) Innovation in service ecosystems-breaking, making, and maintaining institutionalized rules of resource integration. J Bus Res 69(8):2964-2971

Lee S (2015) The age of quality innovation. Int J Qual Innov 1(1):1-9

Lee S, Olson D (2010) Convergenomics: strategic innovation in the convergence era. Gower, Surrey

Lusch RF, Nambisan S (2015) Service innovation: a service-dominant logic perspective. MIS Quart 39(1):155-175

Lusch RF, Vargo SL (2014) Service-dominant logic. premises, perspectives, possibilities. Cambridge University Press, Cambridge

Mas-Tur A, Soriano DR (2014) The level of innovation among young innovative companies: the impacts of knowledge-intensive services use, firm characteristics and the entrepreneur attributes. Serv Bus $8(1): 51-63$

Michel S, Brown S, Gallan A (2008) An expanded and strategic view of discontinuous innovations: deploying a service-dominant logic. J Acad Mark Sci 36(1):54-66

Nambisan S, Sawhney M (2007) The global brain: your roadmap for innovating faster and smarter in a networked world. Wharton School Publishing, Upper Saddle River

Ordanini A, Parasuraman A (2011) Service innovation viewed through a service dominant logic lens: a conceptual framework and empirical analysis. J Serv Res 14(1):3-23

Prahalad CK, Ramaswamy V (2004) The future of competition: co-creating value with customers. Harvard Business School Press, Boston

Vargo SL, Lusch RF (2004) Evolving to a new dominant logic for marketing. J Mark 68(1):1-17

Vargo SL, Lusch RF (2006) The service dominant logic of marketing. Dialog, debate and directions. Sharpe, New York

Vargo SL, Lusch RF (2008) Service-dominant logic: continuing the evolution. J Acad Mark Sci 36(1):1-10

Vargo SL, Maglio PP, Akaka MA (2008) On value and value co-creation: a service systems and service logic perspective. Eur Manag J 26(3):145-152 